\title{
Assessment of the nutritional status of residents in homes for the elderly in Lattakia, Syrian Arab Republic
}

\author{
F.A. Hallaj'
}

$$
\text { تقفيم الحالة الغذائية لدى نزلاء دور المسنين في مدينة اللاذقية بالجمهورية العربية السورية }
$$

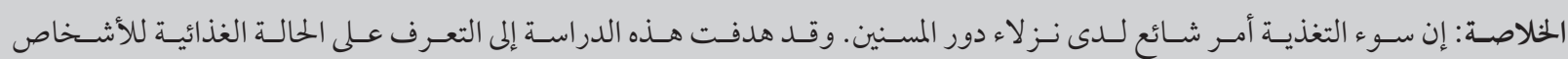

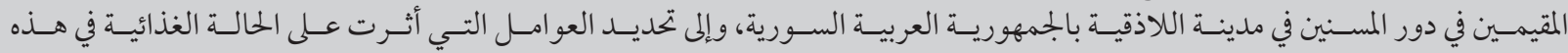

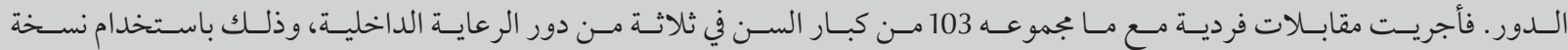

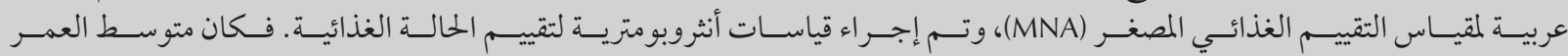

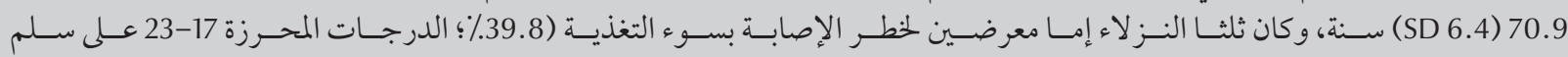

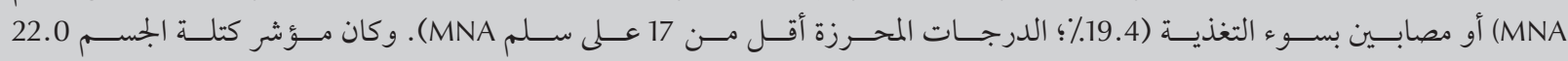

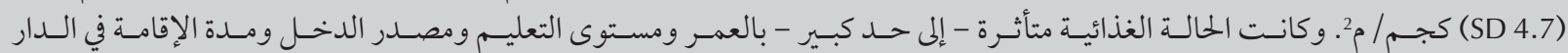

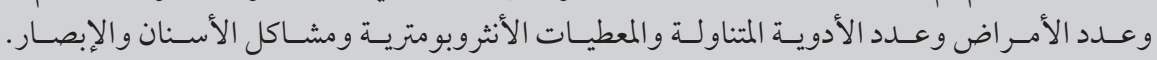

ABSTRACT Malnutrition is common among residents of homes for the elderly. This study aimed to identify the nutritional status of people in residential homes for the elderly in Lattakia, Syrian Arab Republic, and to determine the factors that affected nutritional status in these homes. A total of 103 elderly people in 3 residential homes were interviewed individually using an Arabic version of the Mini Nutritional Assessment (MNA) scale, and anthropometric measurements were carried out to assess nutritional status. The mean age was 70.9 (SD 6.4) years. Two-thirds of residents were either at risk of malnutrition (39.8\%; score 17-23 on the MNA) or malnourished (19.4\%; score $<17$ on the MNA). Mean body mass index was 22.0 (SD 4.7) kg/ $\mathrm{m}^{2}$. Nutritional status was significantly affected by age, level of education, source of income, duration of stay in the home, number of diseases, number of medicines taken, anthropometric data and teeth and vision problems.

Évaluation de l'état nutritionnel des résidents de maisons de retraite à Lattaquié (République arabe syrienne)

RÉSUMÉ La malnutrition est fréquente chez les résidents des maisons de retraite. La présente étude visait à déterminer l'état nutritionnel des résidents des établissements pour personnes âgées à Lattaquié (République arabe syrienne) ainsi que les facteurs qui influent sur cet état nutritionnel dans ces résidences. Au total, 103 personnes âgées dans trois maisons de retraite ont été interrogées en entretien individuel en recourant à la version en langue arabe de l'échelle d'évaluation de l'état nutritionnel Mini Nutritional Assessment (MNA), et des mesures anthropométriques ont été réalisées pour évaluer leur état nutritionnel. L'âge moyen était de 70,9 ans (ET 6,4) . Les deux tiers des résidents étaient soit à risque de malnutrition (39,8\% ; score 17-23 sur l'échelle MNA), soit malnutris $\left(19,4 \%\right.$; score $<17$ sur l'échelle MNA). L'indice de masse corporelle moyen s'élevait à $22,0 \mathrm{~kg} / \mathrm{m}^{2}$ (ET 4,7). L'âge, le niveau d'études, la source de revenu, la durée de séjour en maison de retraite, le nombre de maladies, le nombre de médicaments pris, les données anthropométriques, les problèmes de dentition et de vision influaient nettement sur l'état nutritionnel. 


\section{Introduction}

The increase in the elderly population is a global phenomenon reflecting the increase in life expectancy that has changed the demographic profile of several countries. It follows that the health of this population has become a concern in many societies worldwide. Among the many health issues being investigated, the nutritional status of the elderly population has gained attention. The prevalence of malnutrition is increasing in this population, and this has a negative influence on elderly peoples' health and quality of life (1).

Nutrition is an important element of health, and good nutrition is a vital factor for good health. Many factors affect nutritional status in elderly people; the ageing process is associated with reduced appetite and energy expenditure coupled with a decline in biological and physiological functions such as reduced lean body mass, changes in cytokine and hormone levels, changes in fluid electrolyte regulation, poor dentition, delay in gastric emptying and diminution in the sense of smell and taste $(2,3)$. In addition, chronic diseases and psychological illnesses such as depression, dementia and cognitive disabilities all play a role in the complex etiology of malnutrition in the elderly $(4,5)$. Other factors such as financial concerns and relocation may also affect a person's eating patterns, either through limited food choices or loneliness and lack of social interaction that diminishes enjoyment in eating, which in turn affects food intake $(6,7)$. Malnutrition in the elderly is a major concern because it can have adverse outcomes. It has been associated with a decline in functional status, impaired muscle function, decreased bone mass, immune dysfunction, anaemia, reduced cognitive function, poor wound healing, delayed recovery from surgery, higher hospital readmission and higher mortality rates $(8,9)$. Obesity too can be a problem affecting older people and this contributes to hypertension and diabetes and is associated with increased risk of cancer, coronary heart disease and stroke $(10,11)$.

Malnutrition is common among residents of homes for the elderly and studies indicate that nutritional status can decline within a period of less than 3 months. Therefore, residents who are at risk of developing malnutrition go unrecognized because the anthropometric parameters of elderly people are recorded rarely $(12-18)$. Research shows that if nutritional needs are ignored, the health outcomes of older people will be worsened, and this can have a substantial impact on health and disease, particularly in countries of the Eastern Mediterranean Region, where insufficient attention is given to this issue. Therefore, studies are needed to draw attention to the need for further research in this area, in the Syrian Arab Republic and elsewhere in the Region.

Studies about the Syrian elderly population and their nutritional care in institutions are still scarce. Therefore it was expected that this study would add valuable information about the magnitude of the problem and be beneficial for solving problems associated with malnutrition in the elderly. As nutritional modulation represents one possible approach to successful ageing, we could use the results of this study as a baseline to develop a nutritional guide for homes and in training the staff who provide care for elderly people. We could also use it as a base for continued assessment of the elderly people. The aim of this study therefore was to identify the nutritional status of the residents of homes for the elderly in Lattakia, Syrian Arab Republic, and to determine the factors that affect nutritional status in these homes.

\section{Methods}

\section{Setting}

The study was carried out in the 3 available residential homes for elderly people in Lattakia, Syrian Arab Republic. These are affiliated to social associations under the supervision of the Directorate of Social Security in Lattakia, which is under the Ministry of Social Security. The admission requirements to these homes are being age 60+ years old and free of mental and communicable diseases. The homes are sponsored by charities and donors and the services provided to residents include housing, food, health and recreational services. The services are paid for those who can afford them and free-of-charge for those who cannot. The recreational activities include parties and trips according to the available endowments.

The staff who supervise the homes are not professionals, there is no medical team, no geriatric doctor or gerontological nurse, no nutritionists and no individualized diet, no psychiatrist, no social worker, and the caregivers are unqualified to give care to elders. The workforce in each home comprises a manager with a secondary or university education and 5 to 10 workers who are mostly illiterate, with some who can just read and write and a very few educated who have primary/preparatory or secondary education. In each home a doctor visits the elders once per week to provide medical and follow-up care for those who are in need; this includes free medical care and medication obtained from donations. In case of emergency the elders are transferred to a government or private hospital, depending to their economic status.

Residential home 1: accepts only men and can accommodate up to 36 elders. The building consists of 2 floors and a garden. The first floor includes the kitchen and laundry room, and each floor consists of 4 rooms, bathroom and toilet. The number of elders in each room varies between 2 and 7. Residential home 2 accepts both men and women, up to 43 elders. The home building consists of 3 floors and a garden. On the ground floor there is the kitchen and laundry room, living and dining room, 
toilet and the manager's room. Each of the other 3 floors comprise a kitchenette and 8 rooms each with a private bathroom. The number of elders in each room is 1 or 2. Residential home 3 accepts only women and can accommodate up to 41 elders. The home building consists of 4 floors. Each floor consists of a living room, 4 rooms, bathroom and toilet. The kitchen and laundry room are on the first floor. The number of elders in each room is around 1 to 4 .

\section{Subjects}

All elderly people aged $60+$ years resident at the homes and who agreed to participate in the study were included. Out of the total of 120 elderly people 103 consented to participate (8 people refused to participate in the study and 9 did not meet the study criteria). A few of the 103 participants initially refused to talk but the researcher was able to involve friends to persuade them or to attend the interview to make them feel secure and to cooperate.

\section{Tools}

Two tools were used to collect the study data. The first was a questionnaire designed by the researcher and included items related to: sociodemographic characteristics of the elderly person (age, sex, social status, level of education, occupation before retirement, monthly income, duration of stay in the home); medical history; and presence of chronic disease and physical limitations that might affect their ability to eat independently.

The second tool was the Mini Nutritional Assessment scale, which was designed by Guigoz in 1994 and modified by Kaiser in 2009 (19). It is a specialized screening tool for elderly people and is used to identify those who are malnourished or at risk of malnutrition. It consists of 2 parts: the first part (screening) includes 6 questions about: food intake; weight loss; mobility; psychological stress or acute disease; neuropsychological problems; and body mass index (BMI). The second part includes questions about: independent living; number of prescription drugs taken per day; presence of skin ulcers; number of meals eaten per day; protein and fruit or vegetable intake per day; fluid intake per day; mode of feeding; self-perception of nutritional status; self-perception of health status; and mid-arm circumference $(\mathrm{cm})$ and calf circumference $(\mathrm{cm})$. The maximum score is 30. An individual's nutritional status is classified according to the score obtained as: normal nutritional status (score 24-30); at risk of malnutrition (score 17-23.5); or malnourished (score $<17$ ).

The Mini Nutritional Assessment scale (19) has been validated in many research studies with elderly people in hospital, nursing home, ambulatory care and community settings. Studies have demonstrated internal consistency and inter-observer reliability $(r=$ 0.89) (20-26). The Hartford Institute for Geriatric Nursing, New York University, College of Nursing, is cited as the source (19). After translation of the scale into Arabic by the researcher, the study tools were tested for content validity by 5 experts in the field of the study. Reliability was done using the test-retest method (after 2 weeks) applied to 20 elderly people. Spearman correlation coefficient for the Arabic version of the Mini Nutritional Assessment was 0.98 .

\section{Data collection}

Data collection started from 10 June to the middle of August 2014. Each resident who met the study criteria was interviewed individually by the researchers using the questionnaire and Mini Nutritional Assessment scale (19). Anthropometric measurements were made in order to identify nutritional status and associated factors. The time of the interview ranged from 1 hour to 1.5 hours, depending on the level of understanding and cooperation of the participants. Information about chronic diseases was obtained from the individual's medical records.

Official approvals to carry out the study were obtained from the competent authorities. Informed consent to participate in the study was obtained from the elderly people after explanation of the purpose of the study.

\section{Statistical analysis}

The data were analysed using Stata, version 6 . The chi-squared test and Fisher exact test were used to compare between 2 qualitative variables or 2 proportions. The Student $t$-test was used to compare between means and standard deviation (SD). Analysis of variance was used with more than 2 means. $P$-value $\leq 0.05$ was considered significant.

\section{Results}

\section{Background characteristics of residents}

The age of the elderly people ranged from 61 to 84 years, with a mean of 70.9 (SD 6.4) years. There were 56 females and 47 males. Almost two-thirds (60.8\%) of the residents were widowed. Half (47.6\%) of the sample had up to preparatory level education, $40.0 \%$ had not worked outside the home (i.e. housewives) before their admission to the residential home and $42.7 \%$ depended on their pension. The duration of stay in the home ranged from 3 months to 14 years, with a mean of 4.9 (SD 3.2) years (Table 1).

Just $60.2 \%$ of residents had chronic diseases, most commonly cardiovascular disorders (26.2\%), gastrointestinal disorders (19.4\%), musculoskeletal disorders (14.6\%) and depression (13.6\%) (Table 2).

Concerning the anthropometric characteristics of the elderly people, the mean height was $165.2($ SD 9.8) cm, mean weight was 59.9 (SD 12.7) kg, mean mid-arm circumference was 24.4 (SD 3.4$) \mathrm{cm}$, mean calf circumference 


\begin{tabular}{|c|c|c|}
\hline Variable & No. of residents & $\begin{array}{c}\% \\
(n=103)\end{array}$ \\
\hline \multicolumn{3}{|l|}{ Age (years) } \\
\hline $60-$ & 47 & 45.6 \\
\hline $70-$ & 45 & 43.7 \\
\hline$\geq 80$ & 11 & 10.7 \\
\hline Mean (SD) & \multicolumn{2}{|c|}{$70.9(6.4)$} \\
\hline \multicolumn{3}{|l|}{ Sex } \\
\hline Female & 56 & 54.4 \\
\hline Male & 47 & 45.6 \\
\hline \multicolumn{3}{|l|}{ Marital status } \\
\hline Widowed & 62 & 60.2 \\
\hline Divorced & 20 & 19.4 \\
\hline Single & 17 & 16.5 \\
\hline Married & 3 & 2.9 \\
\hline \multicolumn{3}{|l|}{ Educational level } \\
\hline Up to preparatory & 49 & 47.6 \\
\hline Secondary & 40 & 38.8 \\
\hline Higher education & 14 & 13.6 \\
\hline \multicolumn{3}{|c|}{ Occupation before retirement } \\
\hline Housewife & 40 & 38.8 \\
\hline Employee & 30 & 29.1 \\
\hline Business & 13 & 12.6 \\
\hline Technical worker & 20 & 19.4 \\
\hline \multicolumn{3}{|l|}{ Source of income } \\
\hline Pension & 44 & 42.7 \\
\hline Relative and friends & 31 & 30.1 \\
\hline Social affairs & 28 & 27.2 \\
\hline \multicolumn{3}{|c|}{ Duration of stay in the home (years) } \\
\hline$<1$ & 10 & 9.7 \\
\hline $1-$ & 51 & 49.5 \\
\hline $5-$ & 33 & 32.0 \\
\hline $10+$ & 9 & 8.7 \\
\hline Mean (SD) & \multicolumn{2}{|c|}{$4.9(3.2)$} \\
\hline
\end{tabular}

$S D=$ standard deviation .

was $32.5(\mathrm{SD} 3.4) \mathrm{cm}$, mean skinfold thickness was 13.3 (SD 4.4) $\mathrm{cm}$ and mean BMI was $22.0($ SD 4.7$) \mathrm{kg} / \mathrm{m}^{2}$ (Table 3).

\section{Prevalence of nutritional disorders}

Two-thirds of the participants suffered from nutritional disorders according to the total results of the Mini Nutritional Assessment (score < 23); 39.8\% were classified as at risk of malnutrition (score 17-23) and 19.4\% as malnourished $($ score < 17) $($ Table 4).

Nutritionalstatuswassignificantlyaffected by age, level of education, source of income, duration of stay in the home, number of chronic diseases, number of medicines taken, teeth problems and vision problems (all $P \leq 0.001)$. Residents who were older, with a longer duration of stay in the home, of lower education status and with income from social affairs (rather than a pension or relatives) were more likely to be malnourished. Malnourishment was also more common in those with a worse clinical picture (i.e. more chronic illnesses, taking more prescription medications, with teeth problems and vision problems). All the anthropometric variables correlated with malnutrition (i.e. lower weight, lower mid-arm circumference, lower calf circumference, lower skinfold thickness and lower BMI $)(P=0.0226$, $P \leq 0.001, P \leq 0.001, P=0.0087$ and $P=$ 0.0413 respectively) (Table 5).

\section{Discussion}

Our findings indicate that one-fifth of the elderly residents of the homes were malnourished and two-fifths were at risk of malnutrition. This is probably because the majority of them ate only 1 meal daily and they did not consume the needed quotas of nutrients such as protein, legumes, milk and milk products, vegetables and fruits, and did not drink an adequate amount of water. Even though the homes offered 3 meals per day the majority of residents ate only the lunch meal, which was the only meal provided at a fixed time. Because of the limited budget of the homes and their dependence on endowments, they focused only on the quality of the lunch meal, based on the view that it was the basic meal of the day, and ignored the quality of both the breakfast and the dinner meals. As a consequence some elderly people did not take these because of they were not satisfied with the quality of the meals. Unlike those who have money, those who depend on endowments have no means to replace inadequate meals with meals from outside the home.

In addition, there was no follow-up from the staff on consumption of meals by the elderly people, and there were no daily records for the meals eaten and their content. The lack of qualified staff and nutritionists/dieticians meant that 


\begin{tabular}{|c|c|c|}
\hline Health profile & No. & $\begin{array}{c}\% \\
(n=103)\end{array}$ \\
\hline \multicolumn{3}{|l|}{ Teeth problems } \\
\hline No & 30 & 29.1 \\
\hline Yes & 73 & 70.9 \\
\hline \multicolumn{3}{|l|}{ Vision problems } \\
\hline No & 29 & 28.2 \\
\hline Yes & 74 & 71.8 \\
\hline \multicolumn{3}{|l|}{ Chronic diseases $^{a}$} \\
\hline None & 41 & 39.8 \\
\hline Cardiovascular disease & 27 & 26.2 \\
\hline Gastrointestinal tract disorder & 20 & 19.4 \\
\hline Musculoskeletal disorder & 15 & 14.6 \\
\hline Depression & 14 & 13.6 \\
\hline Urinary disorder & 8 & 7.8 \\
\hline Metabolic disorder & 6 & 5.8 \\
\hline Respiratory disorder & 1 & 1.0 \\
\hline \multicolumn{3}{|l|}{ Medications taken ${ }^{a}$} \\
\hline None & 27 & 26.2 \\
\hline Anti-hypertensive & 24 & 23.3 \\
\hline Laxative & 20 & 19.4 \\
\hline Anti-inflammatory and analgesic & 18 & 17.5 \\
\hline Anti-depressant & 16 & 15.5 \\
\hline Diuretic & 16 & 15.5 \\
\hline Vitamins and minerals & 16 & 15.5 \\
\hline Antacid & 14 & 13.6 \\
\hline Aspirin & 13 & 12.6 \\
\hline Hypoglycaemic & 6 & 5.8 \\
\hline Digoxin & 3 & 2.9 \\
\hline Antibiotic & 2 & 1.9 \\
\hline Potassium chloride & 1 & 1.0 \\
\hline
\end{tabular}

${ }^{a}$ More than one answer was possible.

the homes did not consider the individualized needs of the residents, the chronic diseases they had, the adequacy

of caloric content, protein, fibre, other nutrients and fluids which need special attention and there was no follow-up

\begin{tabular}{lc}
\hline $\begin{array}{l}\text { Table } 3 \text { Distribution of residents of homes for the elderly according to their } \\
\text { anthropometric measurements }\end{array}$ \\
\hline Anthropometric measurement & Mean (SD) \\
Height $(\mathrm{cm})$ & $165.4(9.8)$ \\
Weight $(\mathrm{kg})$ & $59.9(12.7)$ \\
Mid-arm circumference $(\mathrm{cm})$ & $24.4(3.4)$ \\
Calf circumference $(\mathrm{cm})$ & $32.5(3.4)$ \\
Skinfold thickness $(\mathrm{cm})$ & $13.3(4.4)$ \\
Body mass index $\left(\mathrm{kg} / \mathrm{m}^{2}\right)$ & $22.0(4.7)$ \\
\hline
\end{tabular}

$S D=$ standard deviation.

of how much water the elderly people were drinking. Elderly people may not be aware of the importance of water and may avoid drinking because of fears about going to the toilet during the night.

Other data from the Mini Nutritional Assessment [not presented here] indicated that some of the residents had suffered a decline in food intake over the past 3 months which had caused noticeable weight loss. In contrast, a few elderly people had depression which caused the opposite effect and increased eating which led to obesity. This supports the findings of some studies $(13,27,28)$, but contradicts those of other studies in which higher figures were reported $(14,17)$. This observed differences can be attributed to religious and cultural differences, as most of these studies were made in non-Arab countries that differ in climate and eating habits and where residents may drink alcohol, which is not permitted in the studied homes.

The age of the elderly people significantly affected their nutritional status, as the mean age of malnourished elderly people was higher than those with normal nutritional status. This is probably due to the changes associated with ageing that may affect food digestion and metabolism. The same findings were reported in other studies $(14,17)$.

Nutritional status was significantly affected by the level of education; malnutrition was more often found among the elderly people with low education, while none of those with higher education had malnutrition. This can be explained by elderly people with low education not having adequate information about nutrient needs and their sources. Early lifestyle patterns of educated elderly people are likely to be different from those of the uneducated and they may be more aware about sources of nutrients and their needs. The same findings were reported in another study (28). 


\begin{tabular}{|c|c|c|c|}
\hline Nutritional status (score) & No & $\begin{array}{c}\% \\
(n=103)\end{array}$ & Mean (SD) score \\
\hline Screening (total score 14) & & & $10.2(3.2)$ \\
\hline Normal nutritional status (score 12-14) & 42 & 40.8 & \\
\hline At-risk of malnutrition (score 8-11) & 43 & 41.8 & \\
\hline Malnourished (score 0-7) & 18 & 17.5 & \\
\hline Assessment (total score 16) & & & $10.6(2.9)$ \\
\hline Total assessment (total score 30) & & & $20.8(6.0)$ \\
\hline Normal nutritional status (score 24-30) & 42 & 40.8 & \\
\hline At-risk of malnutrition (score 17-23) & 41 & 39.8 & \\
\hline Malnourished (score < 17) & 20 & 19.4 & \\
\hline
\end{tabular}

$S D=$ standard deviation.

It was found that their source of income affected the elderly people's nutritional status. Residents who had a stable source of income had normal nutritional status while those who depended on assistance from the social affairs department were more likely to be malnourished or at risk of malnutrition. This is expected because the studied homes had limited resources, so the food that was provided might not contain all the necessary nutrients, and elderly people who depended on social welfare had no money to buy supplementary food richer in nutrients from outside the home. It is likely that often choices needed to be taken between buying food and paying for other necessities such as medications. Also, it was noticed that elderly people who had their own pension were healthier and had no nutritional problems, as they were able to obtain food that compensated for the missing nutrients from outside the home. This supports the findings of another study (1).

The study revealed that the longer the duration of stay in the home the worse was the nutritional status of the elderly people. This may be because the nutrition schedule at the residential home may not meet the elderly person's preferences and this could affect their appetite and interest in food over the long term. Also some elderly people like to prepare their food by themselves which was not a possibility in these homes. In addition, a longer duration of stay is associated with increased psychological and social problems, such as loneliness, social isolation and depression which can cause self-neglect and decreased interest in food and a subsequent decrease in the intake of nutrients. This supports the findings of other studies $(14,15)$.

A significant relationship was also observed between nutritional status and the number of diseases. All the elderly people who had more than 3 diseases were malnourished while those with no diseases or only 1 disease mostly had normal nutritional status. This can be due to the fact that the disease increases metabolic needs, in addition to the pathophysiological effects of the disease that may affect the gastrointestinal tract and lead to loss of appetite, difficulties in chewing or swallowing, digestion, absorption and metabolism. It can also affect elderly people's ability to prepare food and feed themselves, as elderly people sometimes become bedor chair-bound, so they may become depressed and lose the motivation and desire to eat. Moreover, dementia and confusion can impair elderly people's desire to eat and their ability to feed themselves by interfering in choice of foods to eat, getting food into the mouth and chewing. This result is in line with other studies $(3,4)$.
Teeth and vision problems also had a significant relationship with nutritional status. Poor dentition can cause difficulty in chewing food and swallowing, leading to a decrease in nutrient intake. Also, those with visual problems who did not use glasses were unable to prepare foods and feed themselves, which in turn can lead to loss of appetite, motivation and interest. The same was reported in other studies $(18,29)$.

The number of medicines taken by elderly people significantly affected their nutritional status. All the elderly people who had more than 3 prescribed medicines per day were malnourished, while those having no medicines had no nutrition problems. This may be because medicines cause side-effectssuch as decreased appetite, nausea and vomiting, diarrhoea, dry mouth, alterations in taste and smell_-or they may impact absorption, metabolism and excretion of nutrients which all lead to depletion of the essential nutrients. On the other hand, elderly people who had taken vitamin and mineral supplements had normal nutritional status. The same findings were reported in other studies $(3,4)$.

Our findingsindicate that anthropometric measurements-BMI, weight, mid-arm circumference, calf circumference and skinfold thickness - had a significant relationship with nutritional status. Malnourished elderly people had 


\begin{tabular}{|c|c|c|c|c|}
\hline \multirow[t]{3}{*}{ Variable } & \multicolumn{3}{|c|}{ Nutrition status } & \multirow[t]{3}{*}{$P$-value } \\
\hline & Normal & At-risk & Malnutrition & \\
\hline & No. & No. & No. & \\
\hline \multicolumn{5}{|l|}{ Residential home } \\
\hline Home 1 & 33.3 & 50.0 & 16.7 & 0.480 \\
\hline Home 2 & 50.0 & 29.0 & 21.1 & \\
\hline Home 3 & 37.1 & 42.9 & 20.0 & \\
\hline \multicolumn{5}{|l|}{ Sex } \\
\hline Women & 37.5 & 41.1 & 21.4 & 0.695 \\
\hline Men & 44.7 & 38.3 & 17.0 & \\
\hline Age [Mean ( SD) years] & $67.0(4.6)$ & $73.2(6.3)$ & $74.9(5.0)$ & $<0.001$ \\
\hline \multicolumn{5}{|l|}{ Level of education } \\
\hline Up to preparatory & 14.3 & 46.9 & 38.8 & \\
\hline Secondary & 55.0 & 42.5 & 2.5 & $<0.001$ \\
\hline Higher education & 92.7 & 7.1 & 0.0 & \\
\hline \multicolumn{5}{|l|}{ Source of income } \\
\hline Pension & 84.1 & 15.9 & 0.0 & \\
\hline Relatives and friends & 16.1 & 48.4 & 35.5 & $<0.001$ \\
\hline Social affairs & 0.0 & 67.9 & 32.1 & \\
\hline \multicolumn{5}{|c|}{ Duration of stay in the home (years) } \\
\hline$<1$ & 90.0 & 0.0 & 10.0 & \\
\hline $1-$ & 58.8 & 31.4 & 9.8 & \\
\hline $5-$ & 9.1 & 57.6 & 33.3 & $<0.001$ \\
\hline$\geq 10$ & 0.0 & 66.7 & 33.3 & \\
\hline Mean (SD) & $2.6(1.3)$ & $6.6(3.4)$ & $6.5(2.6)$ & \\
\hline \multicolumn{5}{|l|}{ No. of diseases } \\
\hline 1 & 54.6 & 41.6 & 3.9 & \\
\hline 2 & 0.0 & 40.9 & 59.1 & $<0.001$ \\
\hline$\geq 3$ & 0.0 & 0.0 & 100.0 & \\
\hline \multicolumn{5}{|l|}{ No. of medications taken } \\
\hline 0 & 51.9 & 48.2 & 0.0 & \\
\hline 1 & 62.8 & 37.2 & 0.0 & \\
\hline 2 & 6.7 & 80.0 & 13.3 & $<0.001$ \\
\hline$\geq 3$ & 14.0 & 13.0 & 0.0 & \\
\hline \multicolumn{5}{|l|}{ Teeth problems } \\
\hline No & 96.7 & 3.3 & 0.0 & $<0.001$ \\
\hline Yes & 17.8 & 54.8 & 27.4 & \\
\hline \multicolumn{5}{|l|}{ Vision problems } \\
\hline No & 86.2 & 10.3 & 3.5 & \\
\hline Yes & 23.0 & 51.4 & 25.7 & $<0.001$ \\
\hline \multicolumn{5}{|l|}{ Vision problems } \\
\hline No & 23.0 & 51.4 & 25.7 & $<0.001$ \\
\hline Yes & 86.2 & 10.3 & 3.5 & \\
\hline Anthropometric variables [Mea & & & & \\
\hline Height $(\mathrm{cm})$ & $164.2(11.9)$ & $166.7(7.5)$ & $165.2(9.3)$ & 0.520 \\
\hline Weight $(\mathrm{kg})$ & $61.1(8.8)$ & $62.2(11.2)$ & $53.1(19.2)$ & 0.023 \\
\hline Mid-arm circumference $(\mathrm{cm})$ & $25.7(1.8)$ & $25(2.7)$ & $20.7(4.7)$ & $<0.001$ \\
\hline Calf circumference $(\mathrm{cm})$ & $34.2(2.5)$ & $32.8(2.3)$ & $28.5(3.8)$ & $<0.001$ \\
\hline Skin fold thickness $(\mathrm{cm})$ & $14.5(3.2)$ & $13.2(3.4)$ & $10.9(6.8)$ & 0.009 \\
\hline $\mathrm{BMI}\left(\mathrm{kg} / \mathrm{m}^{2}\right)$ & $22.8(1.9)$ & $22.4(4.3)$ & $19.7(8.2)$ & 0.0413 \\
\hline
\end{tabular}

$S D=$ standard deviation 
BMI and body weights of 10-20\% below normal value. Moreover, the other measures such as mid-arm circumference, calf circumference and skinfold thickness were over or under the normal values. On the other hand, the anthropometric measures of elderly people with normal nutritional status were in the normal values. Anthropometric measurements are important indicators of elderly peoples' health as they reflect a balance between intake and energy expenditure, muscle mass, amount of body fat and protein storage. Our results support those of other studies $(3,13,16)$.

No significant relationship was noted between nutritional status and the sex of the individual, and both males and females shared the same risk of malnutrition. The same observation was reported in another study (14). There were also no significant differences in nutritional status among the 3 residential homes. This is unsurprising as each of the 3 homes is a part of a social association that depends on donations, so they have limited financial conditions and insufficient staffing.
Our results provide further evidence that nutrition screening should become an essential part of routine nursing practice when caring for elderly people, in order to identify and treat those who are malnourished or at risk for malnutrition $(1,17)$. More attention should given to observing the obvious signs of malnutrition such as loss of appetite and unintentional weight loss $(18,30)$. Other signs include dull and dry hair, conjunctival dryness, receding gums, mental confusion, sensory loss and motor weakness (19,31). Management requires a holistic approach so that underlying causes such as chronic illness, depression, medication and social isolation can be treated. Elderly people with physical or cognitive impairment require special care and attention $(3,12)$.

Some limitations of the study should be noted. The absence of nutritionists/dietitians and the lack of cooperation from the residential home staff made getting accurate diet information difficult. So it took efforts from the researcher, who spent a lot of time in the studied homes to collect the data either in the morning or afternoon, and sometimes the researcher had to visit some residents several times to complete the work. In addition, a few elderly people had food times different from the fixed meal-times of the homes, which also needed more visits.

\section{Conclusion}

The majority of residents of homes for the elderly in Lattakia suffered from nutritional disorders and could be at risk of malnutrition or malnourishment. Nutritional status was affected by age, level of education, source of income, duration of stay, number of diseases and medicines taken, teeth and visual problems and anthropometric measurements.

\section{Acknowledgements}

\section{Funding: None.}

Competing interests: None declared.

\section{References}

1. Ahmed T, Haboubi N. Assessment and management of nutrition in older people and its importance to health. Clin Interv Aging. 2010;5(1):207-16. PMID:20711440

2. Chapman IM. Nutritional disorders in the elderly. Med Clin North Am. 2006 Sep;90(5):887-907. PMID:16962848

3. Lee JS, Frongillo EA Jr. Nutritional and health consequences are associated with food insecurity among U.S. elderly persons. J Nutr. 2001 May;131(5):1503-9. PMID:11340107

4. Gianna R. Ten factors that affect an older adult's nutrition. Postgraduate Medical Journal: Malnutrition and Ageing. 2012;6(5):307-11.

5. Paker-Eichelkraut HS, Bai-Habelski JC, Overzier S, Strathmann $\mathrm{S}$, Heseker $\mathrm{H}$, Stehle $\mathrm{P}$, et al. Nutritional status and related factors in elderly nursing home residents: comparative crosssectional study in migrants and native Germans. J Nutr Gerontol Geriatr. 2013;32(4):330-42. PMID:24224940

6. Broeska VE, Lengyel CO, Tate RB. Nutritional risk and 5-year mortality of older community-dwelling Canadian men: the Manitoba Follow-Up Study. J Nutr Gerontol Geriatr. 2013;32(4):317-29. PMID:24224939

7. Other nutrition related problems of older people [Internet]. London: The Dairy Council; 2014 (http://www.milk.co.uk/ page.aspx?intPageID=118, accessed 12 July 2015).

8. Lukito MW. The MSD General Practitioner Universities Programme: nutrition in the elderly. Australia: Excerpta Medica Company; 2002. p. 13.
9. Merja S. Nutrition and nutritional care of elderly people in Finnish nursing homes and hospitals [dissertation]. Helsinki: Faculty of Agriculture and Forestry, University of Helsinki; 2007. p. 13 (https://helda.helsinki.fi/bitstream/ handle/10138/20785/nutritio.pdf?sequence=1, accessed 12 July 2015).

10. Living in Britain: results from the 2002 General Household Survey. London: Office of National Statistics; 2004. p. 53.

11. DiMaria-Ghalili Rose. Nursing standard of practice protocol: nutrition in aging. 4th ed. New York: Springer; 2012. p. 101.

12. Keep fit for life. Meeting the nutritional needs of older persons. Geneva: World Health Organization; 2002 (http:// apps.who.int/iris/bitstream/10665/42515/1/9241562102. pdf?ua=1\&ua=1, accessed 13 August 2015).

13. Chen LK, Lin MH, Hwang SJ, Wang P, Chwang LC. Nutritional status and clinical outcomes among institutionalized elderly Chinese in Taiwan. Arch Gerontol Geriatr. 2007 MayJun;44(3):315-23. PMID:16949167

14. Lelovics Z, Bozó RK, Lampek K, Figler M. Results of nutritional screening in institutionalized elderly in Hungary. Arch Gerontol Geriatr. 2009 Jul-Aug;49(1):190-6. PMID:18786738

15. Promoting nutrition in care homes for older people. Edinburgh: Scottish Government, Care Commission; 2009. p. 7 (http://www.dignityincare.org.uk/_library/Resources/Dignity/CSIPComment/promotingnutritionincare_homes1.pdf, accessed 12 July 2015). 
16. Health Council of the Netherlands. Undernutrition in the elderly. Amsterdam: Minister of Health Netherlands; 2011; 20.

17. Gonçalves DF, Tinoco AL, Ribeiro RdeC, Martinho KO, de Mendonça ET, Benfica DT. Nutritional status and epidemiological profile of elderly people. Arch Gerontol Geriatr. 2012 Jul-Aug;55(1):1-4. PMID:21737152

18. Mitsuyoshi Y. Nutrition and oral status in elderly people. Arch Gerontol Geriatr. 2013;1(1):123-8.

19. The Hartford Institute for Geriatric Nursing. Assessing nutrition in older adults. New York (NY): University of New York, College of Nursing; 2012.

20. Bauer JM, Kaiser MJ, Anthony P, Guigoz Y, Sieber CC. The Min Nutritional Assessment-its history, today's practice, and future perspectives. Nutr Clin Pract. 2008 Aug-Sep;23(4):388-96. PMID:18682590

21. Cereda E. Mini nutritional assessment. Curr Opin Clin Nutr Metab Care. 2012 Jan;15(1):29-41. PMID:22037014

22. DiMaria-Ghalili RA, Guenter PA. The mini nutritional asA sessment. Am J Nurs. 2008 Feb;108(2):50-9, quiz 60. PMID:18227672

23. Guigoz Y, Vellas B, Garry PJ. Mini Nutritional Assessment: A practical assessment tool for grading the nutritional state of elderly patients. Facts and Research in Gerontology. 1994;4(2):15-59.

24. Kaiser MJ, Bauer JM, Uter W, Donini LM, Stange I, Volkert D, et al. Prospective validation of the modified mini nutritional assessment short-forms in the community, nursing home, and rehabilitation setting. J Am Geriatr Soc. 2011 Nov;59(11):2124-8. PMID:22092071
25. Loreck E, Chimakurthi R, Steinle NI. Nutritional assessment of the geriatric patient: A comprehensive approach toward evaluating and managing nutrition. Clin Geriatr. 2012;20(4):20-6.

26. Skates JJ, Anthony PS. Identifying geriatric malnutrition in nursing practice: the Mini Nutritional Assessment $\left(M N A^{\circledast}\right)$ an evidence-based screening tool. J Gerontol Nurs. 2012 Mar;38(3):18-27, quiz 28-9. PMID:22329392

27. Hamid AM. A study of obesity among elderly in Alexandria [Master's thesis]. Alexandria, Egypt: University of Alexandria; 1993.

28. Fouad RA, El-Geneidy MM, Fikrat AFE-S, Abdel Moneim S. Assessment of the nutritional status of residents of elderly homes. Bull High Inst Public Health. 2006;36(5):236-57.

29. Wakai K, Naito M, Naito T, Kojima M, Nakagaki H, Umemura $\mathrm{O}$, et al. Tooth loss and intakes of nutrients and foods: a nae tionwide survey of Japanese dentists. Community Dent Oral Epidemiol. 2010 Feb;38(1):43-9. PMID:19922495

30. Expert Working Group of the Caroline Walker Trust. Eating well for older people: practical and nutritional guidelines for food in residential and nursing homes and for community meals. 2nd ed. London: The Caroline Walker Trust; 2004. p. 29.

31. Brotherton AB, Simmonds N, Stroud M, editors. Malnutrition matters meeting quality standards in nutritional care. London: British Association for Parenteral and Enteral Nutrition; 2010. p. 7 (http://www.bapen.org.uk/pdfs/toolkit-for-commissioners. pdf, accessed 12 July 2015). 